\title{
Morphotypological Prevalence of Individuals Assessed by the Method of Global Postural Reeducation by Proprioceptive and Muscular Rebalancing (GPR/PMR)
}

\author{
Nélio Silva de Souza ${ }^{1, *}$, Renan Ramos Barcellos ${ }^{1}$, Ana Carolina G. Martins ${ }^{1}$, \\ Glória M. M. Vianna da Rosa ${ }^{1}$, Marco A. Araújo Leite ${ }^{2}$, Carla P. Ayres da Silva ${ }^{3}$, \\ Silmar Teixeira ${ }^{3}$ and Victor Hugo Bastos ${ }^{3}$ \\ 1 School of Physiotherapy, Serra dos Órgãos University Center (UNIFESO), Teresópolis, \\ 25964-330 Rio de Janeiro, Brazil; renanbarcelllos@live.com (R.R.B.); acgfisio@gmail.com (A.C.G.M.); \\ glrosa@superig.com.br (G.M.M.V.d.R.) \\ 2 Department of Neurology and Neuroscience, Federal Fluminense University/University Antônio Pedro \\ Hospital (UFF/HUAP), Niterói, 24033-900 Rio de Janeiro, Brazil; marcoantonio.araujoleite@gmail.com \\ 3 Department of Biomedical Sciences and Brain Mapping and Funcionality, Federal University of Piauí (UFPI), \\ Parnaíba, 64202-020 Piauí, Brazil; carlaayres7@gmail.com (C.P.A.d.S.); silmarteixeira@ufpi.edu.br (S.T.); \\ bastosvh@gmail.com (V.H.B.) \\ * Correspondence: neliosds@gmail.com; Tel.: +55-21-99504-1558
}

Received: 9 May 2018; Accepted: 29 May 2018; Published: 1 June 2018

\begin{abstract}
Introduction: Postural control integrates information from the visual, vestibular, and proprioceptive systems, controlling the body position in space. Global Posture Reeducation (GPR) is a clinically well-accepted method that mainly addresses the proprioceptive component of this postural system. Although the GPR presents relevant evidence, the postural morphotypology prevalence in the general population is not yet known. Objective: To investigate the morphotypological profile prevalence of individuals evaluated with the GPR method by proprioceptive and muscular rebalancing (GPR/PMR). Methodology: A retrospective cross-sectional study was performed (prevalence analysis) of patients evaluated by the GPR/PMR method at the Physiotherapy School Clinic of the Serra dos Órgãos University Center. The morphotypological evaluation data were collected and stored in a spreadsheet using the Microsoft Office Excel®program, where the prevalence of each morphotypology (opening, closing, and mixed) was calculated. Results: A total of 123 evaluation sheets were analyzed, of which 50 were men (41\%) and 74 were women (59\%) with a mean age of 46 years. In the morphotypological diagnosis, the following values were observed: closing $(n=107 ; 87 \%)$; opening $(n=6 ; 5 \%)$ and mixed $(n=9 ; 7 \%)$. The postural diagnosis in closing $(87 \%)$ presented a statistically significant difference, when compared to the morphotypologies in opening $(p<0.0001)$ and mixed $(p<0.0001)$. Few subjects in the sample $(n=5)$, presented a relation between the mixed work position (standing and sitting) and the mixed morphotypology $(p<0.005)$. Conclusion: The morphotypological profile of the analyzed population appears to be in closing and does not correlate with the individual's work position.
\end{abstract}

Keywords: global postural reeducation; prevalence; morphotypology

\section{Introduction}

By definition, posture is the relative position of the body parts in reference to the gravitational field [1]. The ideal posture provides lower energy expenditure due to the absence of abnormal opposing 
forces, with greater efficiency and pain absence [2]. Postural control is a complex sensorimotor behavior that integrates information from the visual, vestibular, and proprioceptive systems [1,2], controlling the body position in space with dual purposes of stability and orientation, in relation to the body and the environment [3]. Global postural reeducation (GPR) is a widespread and clinically accepted method, which mainly addresses the proprioceptive component of this postural system, aiming to obtain the musculoskeletal balance necessary for the best efficiency of this system [4].

Historically, Françoise Mezièré first described the concept of the "muscular chain", which may be defined as an intertwined set of connective tissue and poly-articular muscles with their fibers oriented in the same direction [4]. After Mezièré, several authors created methods based on their global posture, as Godelieve Struyf (GDS), Philipe Souchard, Leopold Busquet, Michael Nisand, Therèse Bertherat, Veronesi Júnior (GPR by work functional rebalancing), as well as Carlos Barreiros and Alexandre Victoni (GPR/PMR). The muscular chains represent circuits through which the organizing body forces are propagated $[4,5]$. In the clinical context, a postural disorder may lead to shortening of different muscle chains and the main ones involved are the anterior and/or posterior chains [5]. In particular, GPR/PMR evaluation seeks to obtain a morphotypological diagnosis of body posture through of a self-assessment, which may be presented in three conditions: (1) closing; (2) opening, and (3) mixed. In the first, the individual presents a shortening predominance of the anterior muscle flexion chain. In the second, shortening occurs predominantly in the posterior muscle extension chain. In the third and last condition, there is a mixture of the two chains (anterior and posterior; see supplementarymaterial). The technique (GPR/PMR) aims to balance the muscular chains (anterior/posterior and right/left), modulating proprioceptive information (neuromuscular spindle) progressively.

Regardless of the GPR type, all postures originate from the Mezièré concept and have common characteristics, such as trunk alignment and external rotation maintenance of the upper and lower limbs, for instance [5-7]. In general, the GPR method aims to "elongate" the shortened poly articular muscles (rich in type II fibers, force) [6], reducing the spinal reflex excitability (alpha motoneuron) by modulating intrafusal fiber activity (type Ia) [8], modifying the viscoelastic properties of connective tissue [6] by breaking down the abnormal crosslinks of collagen [9]. The method has a goal to increase the tone of the mono- and bi-articular muscles (rich in type I fibers, stability) [5], promoting proprioceptive postural control even in total visually deficient individuals [4]. It is believed that these proprioceptive modulations may also promote neuroplastic changes at the spinal and supraspinal levels (sensorimotor cortex) [10], which would result in definitive changes in the body-based postural scheme. In this context, it has recently been proposed that neuroplasticity in the central nervous system (CNS) after a musculoskeletal disorder may explain the changes in motor control and postural balance [11], indicating that the proprioceptive component is relevant in neuro-orthopedic physiotherapy.

The prevalence studies aim to identify the proportion of individuals who present a particular disease and/or change at a given time [12], allowing the elaboration of prevention strategies and more specific approaches. The main benefit of this study is its application in the control and treatment of health problems in the economically active population [13]. Although GPR is growing by presenting relevant clinical evidence with a strong kinetic-functional base in different clinical contexts, the morphotypological prevalence of the Brazilian and world populations is not yet known. This knowledge may be relevant in the treatment and prevention of spinal disorders. Thus, the present study has a goal to investigate the postural morphotypological profile prevalence of individuals evaluated by the GPR/PMR method.

\section{Materials and Methods}

A retrospective cross-sectional study (prevalence) of patients' charts was performed, which was evaluated in the GPR outpatient clinic of the Physiotherapy School Clinic of the Serra dos Órgãos University Center (UNIFESO) from 2008 to 2017. The work was approved by the UNIFESO ethics committee by number 1.568.291 and followed the ethics declaration of Helsinki (Approval date: 13 May 2016). All the investigators had a commitment to the confidentiality of any information obtained 
through a compromise term for the use of institutional data, and the selected files were in accordance with the proposed criteria.

\subsection{Evaluation Criteria}

We used evaluation cards filled out by two experienced examiners trained for at least 10 years by the GPR/PMR method instructor. The two examiners used a single standardized record for the morphotypological data collection, used in the GPR sector of the Physiotherapy School Clinic of UNIFESO.

\subsection{Inclusion and Exclusion Criteria}

We included in the study the records of individuals evaluated by the GPR/PMR method with age above 18 years since, from that age, work activities become more common. We excluded individuals who had been evaluated by any other GPR method who was under 18 years old and that the analyzed data were not fully filled or were incomprehensible. If there was any doubt in the information to be collected, the participant was discarded to avoid errors in the data collection. All participants presented only musculoskeletal disorders (disc herniation, scoliosis, for example), without neurological disease. Some participants presented hypertension, diabetes or metabolic syndrome that was treated with medications specific to each condition.

\subsection{Data Collection}

The data were collected and stored in a spreadsheet using the Microsoft Office Excel ${ }^{\circledR}$ Professional Plus 2016 (Rio de Janeiro, RJ, Brazil). The subjects were identified in codes (S01, S02, etc.), as well as their gender $(\mathrm{M}=0 / \mathrm{F}=1)$ and the age at the postural evaluation year was calculated according to their birth date. In the worksheet, in all the regions analyzed in the evaluation form, they were coded " 0 " for the region that did not change and " 1 " for the region that presented alteration, to facilitate data collection and statistical analysis. For the (professional) work position, the subject was classified according to the position that spends the most time at work (sitting, standing or mixed). Specifically, in the GPR/PMR evaluation, the morphotypological diagnosis and the specific characteristics of the morphotypologies in the closing, opening, and mixed in the assessment sheet were recorded.

\subsection{Data Analysis}

In the descriptive data analysis stage, the following percentages were calculated: age per decade; genre; morphotypological diagnosis (opening, closing, and mixed) in each of their postural variables (head, shoulders, dorsal spine, pelvis, knees, and foot). The prevalence analysis $(P)$ was calculated from the morphotypological diagnosis, using the following formula: $P=\mathrm{n}^{\text {affected }} / \mathrm{n}^{\text {total}}$; being the number of individuals affected ( $\mathrm{n}^{\text {affected }}$ ) divided by the total number of individuals studied $\left(\mathrm{n}^{\text {total }}\right)$ [12].

In the comparative data analysis stage, its distribution was initially calculated using the Kolomogorov-Smirnov test. Subsequently, a variance analysis (ANOVA) of one factor was used to compare the means obtained in each morphotype (opening, closing and mixed). The Pearson-r correlation test was used to verify the strength of association between the respective morphotypologies and labor positions: (1) closing and sitting; (2) opening and standing position, and (3) mixed posture and standing or sitting positions (mixed position, see Table 1). To verify the reliability between the two examiners who collected the data, an intra-class correlation index (ICC) of the mixed type of two variables $(3,1)$ was used for each morphotypological diagnosis. A value of ICC $<0.4$ is considered poor and values between 0.75 and 1.00 are considered excellent [14]. All analyses were performed using the Statistical Package for the Social Sciences program (SPSS, version 20, São Paulo, SP, Brazil), assuming an alpha significance level of $p \leq 0.05$. 
Table 1. Correlation between morphotypology and work position.

\begin{tabular}{ccccc}
\hline Morphotypology & Work Position & Pearson-r Coefficient & $p$-Value & Strength of Association \\
\hline Closing & Seated & 0.81 & 0.187 & Zero \\
Opening & Standing & -0.37 & 0.343 & Zero \\
Mixed & Mixed (standing or sitting) & 0.23 & $0.005^{*}$ & Perfect \\
\hline
\end{tabular}

* Statistically significant difference $(n=5)$.

\section{Results}

In total, 262 records were analyzed, 123 were selected, and 139 were discarded because they were included in the exclusion criteria. Of the 123 tokens selected, $50(41 \%)$ men and $74(59 \%)$ women were found. Participants presented a mean age (standard deviation; minimum-maximum) of 46.98 (16.61; 18-85). The mean percentage values of the ages by periods are described in Table 2.

Table 2. Characteristics of the sample subdivided by specific periods.

\begin{tabular}{cccccc}
\hline Ages by Period & $18-30$ & $31-40$ & $41-50$ & $51-64$ & $>65$ \\
\hline $\mathbf{N}$ & 24 & 20 & 26 & 33 & 21 \\
Average (SD) & $24(0.40)$ & $20(0.37)$ & $26(0.41)$ & $33(0.44)$ & $21(0.38)$ \\
Average Percentage & $20 \%$ & $16 \%$ & $21 \%$ & $27 \%$ & $17 \%$ \\
\hline
\end{tabular}

$\mathrm{N}$ : number of forms; SD: standard deviation.

Of the 123 records analyzed, a predominance was registered in three labor activities described below (records number; average percentage; mean (standard deviation)): (1) standing $(n=29 ; 24 \%$; $0.24(0.43))$; seated $(n=59 ; 48 \% ; 0.48(0.50))$, and mixed $(n=36 ; 29 \% ; 0.29(0.46))$. As for the morphotypological diagnosis, the following values were observed: closing $(n=107 ; 87 \% ; 0.87(0.34))$; opening $(n=6 ; 5 \% ; 0.5(0.22))$ and mixed $(n=9 ; 7 \% ; 0.7(0.26))$. The percentage analysis of prevalence was higher for the morphotypology in the closing (prevalence of $87 \%$ ) and was calculated as follows: $107 / 123 \times 100=86.99 \%$. The postural diagnosis at closing presented a statistically significant difference when compared with the opening morphotypes $(F(1)=63.15, p<0.0001)$ and mixed $(F(1)=133.33$, $p<0.0001$ ) (see Figure 1). Figure 2 shows the percentage of each of the variables (postural regions) analyzed in the closing morphotype.

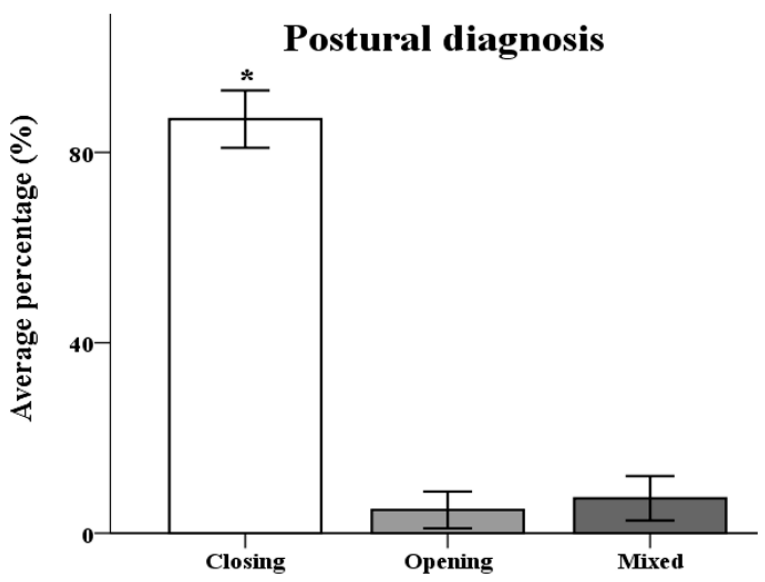

Figure 1. Postural diagnosis of the different morphotypologies. Mean postural diagnosis in the morphologies at closing $(n=107)$, opening $(n=6)$, and mixed $(n=9)$. The closing diagnosis presented a statistically significant difference in relation to the other morphotypologies $\left({ }^{*} p<0.0001\right)$. 


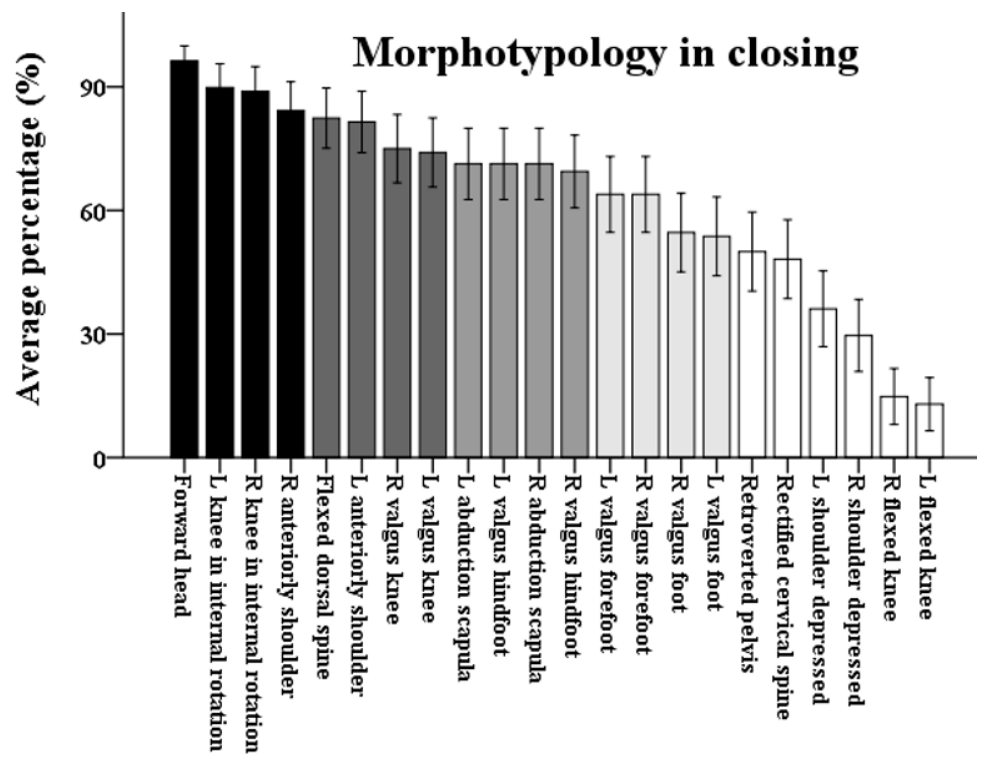

Figure 2. The average percentage of morphotype posture variables in closing. $\mathrm{L}=\mathrm{Left} ; \mathrm{R}=$ Right.

Figure 2 represents the mean percentage of the postural variables evaluated within the morphotypology in closing $(n=107)$. Bars filled in the scale from black to light gray show the variables with a percentage above 50\% change. Note, that the highest percentage values (above 50\%) were observed in the following variables: head anteriorized (96\%); flexion dorsal (78\%); anterior shoulders ( $>80 \%)$; abducted scapula $(67 \%)$; and right and left foot valgus (54\%, Figure 2$)$.

When correlating the work position with the respective morphotypology, it is observed that, of the nine records in which the subjects reported a mixed work position (standing or sitting), five presented a mixed morphotypology (anterior and posterior chains, see Table 1). The ICC values analysis for inter-examiner reliability did not present statistical difference for the morphotypologies in closing (ICC $=-0.056 ; p=0.59$ ), opening (ICC $<0.00 ; p=0.49$ ), and mixed (ICC $=-0.27 ; p=0.54$ ), indicating that there are no differences between the two evaluators.

\section{Discussion}

A patient records analysis $(n=123)$ was performed and evaluated at the GPR clinic of the Physiotherapy School of UNIFESO from 2008 to 2017. The present study had as general objective to investigate the morphotypological prevalence of the individuals evaluated by the GPR/PMR method. The results showed that $87 \%$ of the sample $(n=107)$ had a morphotypology in closing (Figure 1 ) and there was no correlation with the work position in this group (see Table 1). However, the mixed group $(n=5)$ presented a correlation between posture and work position. Within the morphotypology in closing, the most frequent variables (above $50 \%$ ) were: anterior head (96\%); flexion dorsal (78\%); anterior shoulders (>80\%); abducted scapula (67\%); and right and left foot valgus (54\%, Figure 2).

In practical terms, the GPR method presents relevant evidence, involving different types of study: randomized and controlled; non-randomized and controlled; observational studies and case report [5]. This method presents wide clinical acceptance and relevant evidence in different contexts, such as rheumatologic, orthopedic, neurological, and cardiopulmonary.

In the rheumatology area, it has shown an effect in the treatment of fibromyalgia [13] and ankylosing spondylitis [15]. In orthopedics, recently a meta-analysis has shown its effectiveness in spinal column disorders [16], as in the treatments of scoliosis [17,18], herniated disc [19], and Scheuermann's disease (dorsal hyperciphosis) [20,21]. In addition, other effects have been observed, such as improvement: in the distribution of the plantar pressure center [22]; flexibility, range of body movement 
and quality of life [23]; in postural correction [24,25]; in the treatment of temporomandibular disorder [26,27], cervical [23], and low back pain [6,28].

This method has been used in the urinary incontinence treatment [29,30], as well as in the neurological field, in the cervical dystonia treatment [31], stroke [32], and Parkinson's disease [33,34], since its use may promote changes in the motor potential evoked spinal and supraspinal [10]. Finally, in the cardiopulmonary scope, pieces of evidence have been presented in the cardiovascular system response [35]; and in the chronic obstructive pulmonary disease treatment [36], since it has been observed an improvement in respiratory muscle strength and an increase in thoracic cavity mobility after the technique application [37].

In general, the GPR method aims to "elongate" the shortened poly-articular muscles (rich in type II fibers; force) [6], reducing the excitability of the spinal reflex (alpha motoneuron) by modulating intra-fusal fiber activity (type Ia) [8], modifying the viscoelastic properties of connective tissue [6] by breaking down the abnormal crosslinks of collagen (endo, peri and epimisium) [9]. The method has a goal to increase the tone of the mono- and bi-articular muscles (rich in type I fibers; stability) [5], promoting proprioceptive postural control [4] and the decrease of oscillation of the pressure center in the anteroposterior direction [22]. It is believed that these proprioceptive modulations may also promote neuroplastic changes at the spinal and supraspinal levels (sensorimotor cortex) [10], which would result in definitive changes in the body-based postural scheme through the neural plasticity event (gene transcription) [11].

Individuals with anterior posture, clinically known as anterior scapular pattern [2], present a shortening of the anterior flexion chain (morphotypology in closing). Statistically, $72 \%$ of the French population had an anterior scapular pattern (morphotypology in closing) and $43.8 \%$ had right and left valgus feet [2]. In the present study, $87 \%$ of the sample $(n=107)$ presented a morphotypology in closing (Figure 1) and 54\% presented right and left valgus feet (Figure 2), which, in the morphotypological analysis, is represented by valgus in the hindfoot and forefoot. In this context, the results found in the present study corroborates those described in the literature.

The prevalence studies aim to identify the proportion of individuals presenting a particular disease and /or alteration at a given time [12], enabling the prevention strategies elaboration, improving comprehensive health care and guiding therapeutic approaches. The main benefit of this study is its application in the control and treatment of health problems in the economically active population [13]. In this study results, the most affected age group is part of the population considered economically active (41 to 64 years old, see Table 2).

The present study is the first one involving morphotypologic prevalence, regardless of the GPR type. Therefore, it is not yet possible to establish a concrete discussion on the subject, since work is needed in other Brazilian states as well as in other countries of the world.

\section{Conclusions}

The morphotypological profile of the analyzed population $(n=123)$, specifically in Teresópolis, state of Rio de Janeiro, appears to be in the closing and does not correlate with the individual's work position. The posture in flexion (closed chain) may indicate a risk factor for different injuries to the vertebral spine, such as a herniated disc. Therefore, the balance of the anterior and posterior muscle chains can prevent mechanical dysfunctions. It is possible that some variations in the morphotypological profile among the different regions of Brazil according to the culture. Still, the difference may be greater among the countries, due to the diversity of biopsychosocial factors that may influence body posture. As a limitation, the authors did not follow the participants' evolution to verify possible changes in their morphotypological profile. Therefore, more studies are needed to investigate these characteristics and their correlations in Brazil and in the world. 
Supplementary Materials: Supplementary materials can be found at http:/ / www.mdpi.com/2411-5142/3/2/33/ s1.

Author Contributions: N.S.d.S., R.R.B., A.C.G.M., C.P.A.d.S., and G.M.M.V.d.R. participated in the acquisition of data. N.S.d.S., S.T., and V.H.B. participated in the analysis of data SPSS-20. N.S.d.S., M.A.A.L., and V.H.B. guided the design and organization of the study. All authors participated in the revision of the manuscript and gave final approval for the version submitted for publication.

Acknowledgments: This study was supported by a grant-in-aid from Scientific Initiation of Serra dos Órgaos University Center (UNIFESO). The authors thank the coordinators of the course (Doctors Andréa Graniço and Alba Fernandes) for the support to the research.

Conflicts of Interest: The authors declare no conflict of interest.

\section{References}

1. Kandel, E.R.; Schwartz, J.H.; Jessell, T.M.; Siegelbauma, S.A.; Hudspeth, A.J. Principes of Neural Science, 5th ed.; McGraw-Hill Education: New York, NY, USA, 2013.

2. Bricot, B. La Reprogrammation Posturale Globale; Sauramps Médical: Montpellier, France, 2009.

3. Horak, F.B. Postural orientation and equilibrium: What do we need to know about neural control of balance to prevent falls? Age Ageing 2006, 35, 7-11. [CrossRef] [PubMed]

4. Teodori, R.M.; Negri, J.R.; Cruz, M.C.; Marques, A.P. Global Postural Re-education: A literature review. Br. J. Phys. Ther. 2011, 15, 185-190. [CrossRef]

5. Vanti, C.; Generali, A.; Ferrari, S.; Nava, T.; Tosarelli, D.; Pillastrini, P. La rieducazione posturale globale nelle patologie muscolo-scheletriche: Evidenze scientifiche e indicazioni cliniche. Reumatismo 2007, 59, $192-201$. [CrossRef] [PubMed]

6. Bonetti, F.; Curti, S.; Mattioli, S.; Mugnai, R.; Vanti, C.; Violante, F.S.; Pillastrini, P. Effectiveness of a “Global Postural Reeducation" program for persistent Low Back Pain: A non-randomized controlled trial. BMC Musculoskelet. Disord. 2010, 11, 285. [CrossRef] [PubMed]

7. Ferreira, G.E.; Barreto, R.G.; Robinson, C.C.; Plentz, R.D.; Silva, M.F. Global Postural Reeducation for patients with musculoskeletal conditions: A systematic review of randomized controlled trials. Braz. J. Phys. Ther. 2015, 20, 194-205. [CrossRef] [PubMed]

8. Guissard, N.; Duchateau, J.; Hainaut, K. Mechanisms of decreased motoneurone excitation during passive muscle stretching. Exp. Brain Res. 2001, 137, 163-169. [CrossRef] [PubMed]

9. Rosa, G.M.M.V.; Gaban, G.A.; Pinto, L.D.P. Morphofunctional adaptations of skeletal striated muscle related to posture and physical exercise. Fisioter. Brasil. 2002, 3, 100-105.

10. Oliveri, M.; Caltagirone, C.; Loriga, R.; Pompa, M.N.; Versace, V.; Souchard, P. Fast increase of motor cortical inhibition following postural changes in healthy subjects. Neurosci. Lett. 2012, 530, 7-11. [CrossRef] [PubMed]

11. Pelletier, R.; Higgins, J.; Bourbonnais, D. Is neuroplasticity in the central nervous system the missing link to our understanding of chronic musculoskeletal disorders? BMC Musculoskelet. Disord. 2015, 16, 25. [CrossRef] [PubMed]

12. Wagner, M.B. Medindo a ocorrência da doença: Prevalência ou incidência? J. Pediatr. 1998, 74, 157-162.

13. Marques, A.P.; Mendonça, L.L.F.D.; Cossermelli, W. Muscular stretching exercises in patients with fibromyalgia from a training of postural global reeducation (PGR). Rev. Bras. Reumatol. 1994, 34, 232-234. [CrossRef]

14. Cicchetti, D.V. Guidelines, criteria, and rules of thumb for evaluating normed and standardized assessment instruments in psychology. Psychol. Assess. 1994, 6, 284-290. [CrossRef]

15. Silva, E.M.; Andrade, S.C.; Vilar, M.J. Evaluation of the effects of Global Postural Reeducation in patients with ankylosing spondylitis. Rheumatol. Int. 2012, 32, 2155-2163. [CrossRef] [PubMed]

16. Lomas-Vega, R.; Garrido-Jaut, M.V.; Rus, A.; Del-Pino-Casado, R. Effectiveness of global postural re-education for treatment of spinal disorders: A Meta-analysis. Am. J. Phys. Med. Rehabil. 2017, 96, 124-130. [CrossRef] [PubMed]

17. Segura, D.; Do Nascimento, F.C.; Guilherme, J.H.; Sotoriva, P. Effects of global posture reeducation applied to adolescents with idiopathic non-structural scoliosis. Arq. Cienc. Saude UNIPAR 2013, 17, 153-157. 
18. Tavares, G.M.S.; Do Espírito Santo, C.C.; Parizotto, P.; Sperandio, F.F.; Santos, G.M. Treatment of scoliosis by global postural reeducation (GPR) in totally visually impaired individuals: A case series. Sci. Med. 2015, 25, 6. [CrossRef]

19. Di Ciaccio, E.; Polastri, M.; Bianchini, E.; Gasbarrini, A. Herniated lumbar disc treated with Global Postural Reeducation. A middle-term evaluation. Eur. Rev. Med. Pharmacol. Sci. 2012, 16, 1072-1077. [CrossRef] [PubMed]

20. Comerlato, T.; Scanegatta, S.; Rosset, D. Effects of the method of global postural reeducation (RPG) in the treatment of kyphosis scheuermann. Rev. Fisi Senectus. 2013, 1, 10-19.

21. Moreira, L.M.; Sedrez, J.A.; Noll, M.; Candotti, C.T. Effects of global posture re-education (GPR) on thoracic hyperkyphosis: A case study. Arq. Cienc. Saude UNIPAR 2017, 21, 113-117. [CrossRef]

22. Lozano-Quijada, C.; Poveda-Pagán, E.J.; Segura-Heras, J.V.; Hernández-Sánchez, S.; Prieto-Castelló, M.J. Changes in postural sway after a single global postural reeducation session in university students: A randomized controlled trial. J. Manip. Physiol. Ther. 2017, 40, 467-476. [CrossRef] [PubMed]

23. Cunha, A.C.V.; Burke, T.N.; França, F.J.R.; Marques, A.P. Effect of global posture reeducation and of static stretching on pain, range of motion, and quality of life in women with chronic neck pain: A randomized clinical trial. Clinics 2008, 63, 763-770. [CrossRef] [PubMed]

24. Junior, J.R.V.; Tomaz, C. Effects of reeducation posture global by the method (RPG/RFL) of corretion posture and reequilibrum muscle. Fisioter. Mov. 2008, 21, 127-137.

25. Rossi, L.P.; Brandalize, M.; Gomes, A.R.S. Acute effect of global posture reeducation technique in the posture of women with anterior muscular chain shortening. Fisioter. Mov. 2011, 24, 255-263. [CrossRef]

26. Maluf, S.A.; Moreno, B.G.; Crivello, O.; Cabral, C.M.; Bortolotti, G.; Marques, A.P. Global postural reeducation and static stretching exercises in the treatment of myogenic temporomandibular disorders: A randomized study. J. Manip. Physiol. Ther. 2010, 33, 500-507. [CrossRef] [PubMed]

27. Monteiro, W.; Dos Santos, R.M.; Grecco, L.A.C.; Neto, H.P.; Oliveira, C.S. Effectiveness of global postural reeducation in the treatment of temporomandibular disorder: Case report. J. Bodyw. Mov. Ther. 2013, 17, 53-58. [CrossRef] [PubMed]

28. Castagnoli, C.; Cecchi, F.; Del Canto, A.; Paperini, A.; Boni, R.; Pasquini, G.; Vannetti, F.; Macchi, C. Effects in short and long term of global postural reeducation (GPR) on chronic low back pain: A controlled study with one-year follow-up. Sci. World J. 2015, 2015, 271436. [CrossRef] [PubMed]

29. Fozzatti, M.C.M.; Palma, P.; Herrmann, V.; Dambros, M. Impact of global postural reeducation for treatment of female stress urinary incontinence. Rev. Assoc. Med. Bras. 2008, 54, 17-22. [CrossRef] [PubMed]

30. Fozzatti, C.; Herrmann, V.; Palma, T.; Riccetto, C.L.; Palma, P.C. Global Postural Re-education: An alternative approach for stress urinary incontinence? Eur. J. Obstet. Gynecol. Reprod. Biol. 2010, 152, 218-224. [CrossRef] [PubMed]

31. Smania, N.; Corato, E.; Tinazzi, M.; Montagnana, B.; Fiaschi, A.; Aglioti, S.M. The effect of two different rehabilitation treatments in cervical dystonia: Preliminary results in four patients. Funct. Neurol. 2003, 18, 219-226. [CrossRef] [PubMed]

32. Segura, D.C.A.; Nascimento, F.C. Effects of Global Posture Reeducation in Functional Potential of Spastic Hemiparetic Post Stroke. UNOPAR Cient. Cienc. Biol. Saude J. Health Sci. 2011, 13, 221-226.

33. Agosti, V.; Vitale, C.; Avella, D.; Rucco, R.; Santangelo, G.; Sorrentino, P.; Varriale, P.; Sorrentino, G. Effects of Global Postural Reeducation on gait kinematics in parkinsonian patients: A pilot randomized three-dimensional motion analysis study. Neurol. Sci. 2016, 37, 515-522. [CrossRef] [PubMed]

34. Vitale, C.; Agosti, V.; Avella, D.; Santangelo, G.; Amboni, M.; Rucco, R.; Barone, P.; Corato, F.; Sorrentino, G. Effect of Global Postural Rehabilitation program on spatiotemporal gait parameters of parkinsonian patients: A three-dimensional motion analysis study. Neurol. Sci. 2012, 33, 1337-1343. [CrossRef] [PubMed]

35. Abreu, E.M.D.C.; Cunha, T.S.; Júnior, P.; Oliveira, M.A.D. Effect of Global Postural Reeducation on cardiovascular system of healthy subjects. Fisioter. Mov. 2014, 27, 389-397. [CrossRef]

36. Jirkowski, J.; Comerlato, T. Effects of the GPR method in thoracoabdominal mobility and respiratory muscle strength in a copd carrier. Perspect. Erechim. 2015, 39, 155-163. [CrossRef]

37. Moreno, M.A.; Catai, A.M.; Teodori, R.M.; Borges, B.L.A.; De Castro Cesar, M.; Da Silva, E. Effect of a muscle stretching program using the Global Postural Reeducation method on respiratory muscle strength and thoracoabdominal mobility of sedentary young males. J. Bras. Pneumol. 2007, 33, 679-686. [CrossRef] [PubMed] 
(C) 2018 by the authors. Licensee MDPI, Basel, Switzerland. This article is an open access article distributed under the terms and conditions of the Creative Commons Attribution (CC BY) license (http:/ / creativecommons.org/licenses/by/4.0/). 